\title{
Hierarchy of values of students in selected countries of Middle-Eastern Europe in the context of the public trust
}

\author{
Andrzej Borowski \\ Department of Sociology and Social Works, Faculty of Education and Philosophy, \\ Pomeranian University in Słupsk, 64 Westerplatte St., 76-200 Słupsk, Poland \\ E-mail address: aubor@poczta.onet.pl
}

\begin{abstract}
Social trust is related with phenomenon strictly, in Central Europe from over 20 years of social change getting. I have devoted problems of social trust in international investigative project 2009-2012 taking part concerning perception category social trust including country post-communist particular note and from these countries systems of values of young people. Values are declared present by students in daily life frequently definitely than in functioning social structure at the nature institutional-organizational.
\end{abstract}

Keywords: social trust; post-communist countries; system of value; social change

\section{Hierarchia wartości studentów w wybranych krajach Europy środkowo wschodniej w kontekście zaufania społecznego}

\section{STRESZCZENIE}

Zaufanie społeczne jest ściśle związane ze zjawiskiem, zachodzącej w Europie środkowowschodniej od ponad 20 lat zmiany społecznej. W latach 2009-2012 biorąc udział w międzynarodowym projekcie badawczym dotyczącym postrzegania kategorii zaufania społecznego obejmującym kraje postkomunistyczne szczególną uwagę poświęciłem kwestiom zaufania społecznego i systemom wartości młodzieży z tych krajów. Wartości deklarowane przez studentów są zdecydowanie częśsiej obecne w życiu codziennym niż w funkcjonowaniu struktur społecznych o charakterze instytucjonalno-organizacyjnym.

Stowa kluczowe: zaufanie społeczne; kraje postkomunistyczne; system wartości; zmiana społeczna 


\section{WPROWADZENIE}

Zaufanie społeczne jest ściśle związane ze zjawiskiem, zachodzącej w Europie środkowo-wschodniej od ponad 20 lat zmiany społecznej. Znany badacz problematyki zaufania społecznego P. Sztompka zauważa przy tym, iż: "(...) nagłemu poszerzeniu ulega sfera niepewności, ryzyka i zagrożeń, zwiększa się nieprzejrzystość struktur i organizacji (...) Wszystko to podważa poczucie bezpieczeństwa egzystencjalnego, porzadku społecznego, a w efekcie rodzi kryzys zaufania, zarówno horyzontalnego - do innych, jak i wertykalnego - do instytucji publicznych, prowadzac do kultury cynizmu."[1].

Bez zaufania, bez przekonania, że można wierzyć drugiej osobie, nie da się dobrze funkcjonować ani w rodzinie, ani w miejscu pracy, ani w państwie i jego instytucjach. System wartość jaki jest oferowany i przyswajany przez młodzież będzie miał zasadnicze znaczenia dla powodzenia i ugruntowania tych zmian jakie zachodząc mają na celu odbudowanie społeczeństwa obywatelskiego.

Jak wskazują wyniki najnowszych badań nad zaufaniem, w życiu społecznym Polacy są raczej nieufni. Tylko niespełna jedna czwarta badanych (23\%) wychodzi z założenia, że większości ludzi można ufać, blisko trzy czwarte zaś (74\%) wyznaje zasadę zachowywania daleko idacej ostrożności w stosunkach $z$ innymi [2]. Zasada ta powoduje nieufność wobec wartości i instytucji życia publicznego oraz wszelkich działaniań, które zwiększają izolacyjność w społeczeństwie kosztem transparentności są postrzegane negatywnie [3-17].

\section{WYNIKI BADAŃ NAD ZAUFANIEM SPOLECZNYM I SYSTEMEM WARTOŚCI MLODZIEŻY}

W latach 2009-2012 biorąc udział w międzynarodowym projekcie badawczym dotyczącym postrzegania kategorii zaufania społecznego obejmującym kraje postkomunistyczne szczególną uwagę poświęciłem kwestiom zaufania społecznego i systemom wartości młodzieży $\mathrm{z}$ tych krajów. Badaniami objęto młodzież studencką $\mathrm{z}$ Rosji/część europejska/, Ukrainy, Litwy, Czech, Buriacji/część azjatycka Rosji/ i Polski. W ramach projektu przebadano ok. 5 tysięcy respondentów, korzystając $\mathrm{z}$ autorskiego narzędzia badawczego/ ankiety/. Zaufanie jest podstawą współdziałania i elementem który spaja każde społeczeństwo obywatelskie. Pozwala ono obywatelom rozwiązywać problemy i osiągać społeczne cele w sposób bardziej optymalny, przy znacznie mniejszym nakładzie sił i środków. Zaufanie jest również niezbędne w sferze działań społeczności lokalnych jak i przy zawieraniu transakcji finansowych. Zaufanie wzmaga przy tym współpracy, a ta wpływa na wzrost poziomu zaufania. Następuje tzw. sprzężenie zwrotne. W przeciwieństwie do nakładów finansowych, zaufanie to „,zasób moralny”, którego ilość wzrasta, im bardziej się z niego korzysta, a który gdy jest nieużywany zanika [4].

Tabela 1. Najważniejsza wartość życiowa studentów w układzie procentowym.

\begin{tabular}{|c|c|c|c|c|c|}
\hline $\begin{array}{c}\text { Najważniejsza wartość } \\
\text { życiowa/Kraj }\end{array}$ & Czechy & Litwa & Ukraina & Rosja & Polska \\
\hline Dobro rodziny & 38,3 & 49,9 & 25,8 & 32,6 & 38,6 \\
\hline $\begin{array}{c}\text { Więzi emocjonalne } \mathrm{w} \\
\text { rodzinie }\end{array}$ & 13,6 & 9,4 & 6,3 & 8,5 & 8,2 \\
\hline
\end{tabular}




\begin{tabular}{|c|c|c|c|c|c|}
\hline Trwałość rodziny & 6,3 & 2,8 & 6,8 & 11,7 & 11,6 \\
\hline Indywidualizm niezależność & 4,5 & 3,3 & 3,2 & 4,7 & 7,9 \\
\hline $\begin{array}{c}\text { Możliwość } \\
\text { samodoskonalenia }\end{array}$ & 3,6 & 4,1 & 6,2 & 5,7 & 2,4 \\
\hline $\begin{array}{c}\text { Praca zgodna z } \\
\text { zainteresowaniami }\end{array}$ & 2,6 & 6,5 & 3,4 & 2,8 & 3,8 \\
\hline Poczucie bycia potrzebnym & 2,3 & 4,5 & 3,7 & 3,2 & 3,2 \\
\hline $\begin{array}{c}\text { Posiadanie życiowej } \\
\text { odskoczni / azylu/ }\end{array}$ & 2,3 & 0,8 & 1,6 & 1,6 & 1,4 \\
\hline $\begin{array}{c}\text { Praca twórcza /oryginalna/ } \\
\text { Bezpieczeństwo materialne } \\
\text { rodziny }\end{array}$ & 1,0 & 3,7 & 1,0 & 1,6 & 1,8 \\
\hline $\begin{array}{c}\text { Praca dajaca możliwość } \\
\text { awansu }\end{array}$ & 0,1 & 2,0 & 1,3 & 1,8 & 0,4 \\
\hline Szacunek wśród otoczenia & 0,7 & 1,1 & 3,2 & 1,2 & 2,5 \\
\hline
\end{tabular}

Źródło: badania własne w ramach projektu KBN - NN 116438837

We wszystkich badanych krajach wśród studentów wartością dominującą jest dobro rodziny przy czym w największym stopniu akcentują to Litwini, a w najmniejszym Ukraińcy. Stosunkowo niewiele znaczenia $\mathrm{w}$ deklarowanej hierarchi życiowych warotści zajmuje praca zawodowa, zarówno w kontekście awansu społecznego, oryginalności, jak i możliwości samorealizacji.

Tabela 2. Poziom bezrobocia w wybranych krajach Europy.

\begin{tabular}{|c|c|c|c|c|c|}
\hline Stopa bezrobocia & Czechy & Litwa & Ukraina & Rosja & Polska \\
\hline 2012 & 6,8 & 14,3 & 13,3 & 6,4 & 9,2 \\
\hline
\end{tabular}

Źródło: Eurostat, Rosstat, Monthly Bulletin of Statistics online.UN

Zastanawia w badaniach stosunkowo niska deklarowana wartość pracy w stosunku do poziomu bezrobocia w badanych krajach. Dotyczy to zwłaszcza Litwy, Ukrainy i Polski. Najniąszy odsetek bezrobocja w Rosji jest efektem pozostałości po centralnie sterowanym państwowym systemie zarządzania gospodarką i światem pracy.

Tabela 3. Liczba rozwodów w wybranych krajach Europy.

\begin{tabular}{|c|c|c|c|c|c|}
\hline Liczba rozwodów & Czechy & Litwa & Ukraina & Rosja & Polska \\
\hline 2012 & 28047 & 10174 & 118356 & 672624 & 63645 \\
\hline
\end{tabular}

Źródło: eurostat.prognostic.pl 
Wysoki poziom rozwodów w Czechach związany jest $\mathrm{z}$ dominacją agnostycyzmu i liberalizmu obyczajowego w tym kraju a w Rosji i Ukrainie z mentalnością ateistyczną kształtowaną i wspieraną przez poprzedni ustrój. Stosunkowo najniższy poziom rozwodów występuje na Litwie i w Polsce $\mathrm{z}$ uwagi na silne wpływy kościoła katolickiego i tradycje kulturowe.

Tabela 4. Poziom zarobków w wybranych krajach Europy.

\begin{tabular}{|c|c|c|c|c|c|}
\hline Średnia płaca brutto /w euro/ & Czechy & Litwa & Ukraina & Rosja & Polska \\
\hline 2012 & 933 & 533 & 198 & 488 & 868 \\
\hline
\end{tabular}

Źródło: UNECE/Europejska Komisja Gospodarcza ONZ/

Poziom zarobków w badanych krajach wskazuje na zdecydowaną różnicę między poziomem krajów należących do Uni Europejskiej i poza jej strukturami.

Tabele 5-17. Realizacja celów życiowych studentów w wybranych krajach Europy /dane procentowe/.

\begin{tabular}{|c|c|c|c|c|c|}
\hline 5. Stala praca & Czechy & Litwa & Ukraina & Rosja & Polska \\
\hline Cel osiągniety & 4,4 & 8,7 & 6,5 & 5,2 & 24,2 \\
\hline Cel w trakcie osiągania & 8,5 & 21,9 & 37,6 & 42,1 & 22,2 \\
\hline Do 3 lat po ukończeniu studiów & 41,6 & 40,2 & 25,8 & 28,9 & 30,8 \\
\hline Do 5 lat po ukończeniu studiów & 10,7 & 12,1 & 5,8 & 2,8 & 3,5 \\
\hline Później niż 5 lat po ukończeniu \\
studiów & 3,2 & 6,3 & 8,1 & 10,8 & 1,0 \\
\hline Nie zastanawiałem się & 12,0 & 5,8 & 6,2 & 4,5 & 4,3 \\
\hline Nie zamierzam realizować tego celu & 14,2 & 5,0 & 2,5 & 3,4 & 13,4 \\
\hline
\end{tabular}

Źródło: badania własne w ramach projektu KBN - NN 116438837

Najniższe zainteresowanie wczesnym zagwarantowaniem sobie miejsca stałej odpłatnej pracy dominuje wśród Czechów, natomiast największe w Polsce, w Rosji i na Ukrainie. Sytuacja daje się wytłumaczyć poziomem bezrobocia w tych krajach.

\begin{tabular}{|c|c|c|c|c|c|}
\hline 6. Wysoka pozycja zawodowa & Czechy & Litwa & Ukraina & Rosja & Polska \\
\hline Cel osiągniety & 0,8 & 1,9 & 1,6 & 1,7 & 2,6 \\
\hline Cel w trakcie osiągania & 2,2 & 10,2 & 23,0 & 17,5 & 13,2 \\
\hline Do 3 lat po ukończeniu studiów & 12,8 & 21,9 & 29,2 & 32,5 & 31,9 \\
\hline
\end{tabular}




\begin{tabular}{|c|c|c|c|c|c|}
\hline Do 5 lat po ukończeniu studiów & 26,8 & 25,8 & 15,0 & 15,5 & 24,0 \\
\hline $\begin{array}{c}\text { Później niż 5 lat po ukończeniu } \\
\text { studiów }\end{array}$ & 23,2 & 22,2 & 11,4 & 14,2 & 17,2 \\
\hline Nie zastanawiałem się & 20,2 & 13,6 & 9,4 & 10,8 & 7,8 \\
\hline Nie zamierzam realizować tego celu & 9,3 & 3,9 & 2,8 & 5,4 & 2,7 \\
\hline
\end{tabular}

Źródło: badania własne w ramach projektu KBN - NN 116438837

Osiągnięcie wysokiej pozycji zawodowej w kontekście efektu ukończonych studiów w największym stopniu akcentują Polacy, Rosjanie i Litwini, zaś w najmniejszym Czesi. U tych ostatnich wysoka pozycja zawodowa oczekiwana jest w dłuższym okresie po zakończeniu nauki w szkole wyższej.

\begin{tabular}{|c|c|c|c|c|c|}
\hline 7. Stanowisko kierownicze & Czechy & Litwa & Ukraina & Rosja & Polska \\
\hline Cel osiągnięty & 0,7 & 1,4 & 1,0 & 0,5 & 0,7 \\
\hline Cel w trakcie osiągania & 0,8 & 3,8 & 10,2 & 5,8 & 2,1 \\
\hline Do 3 lat po ukończeniu studiów & 3,2 & 5,0 & 13,7 & 13,1 & 4,3 \\
\hline Do 5 lat po ukończeniu studiów & 9,4 & 13,2 & 19,8 & 19,2 & 11,6 \\
\hline Później niż 5 lat po ukończeniu & 25,7 & 24,1 & 12,2 & 15,9 & 25,2 \\
\hline studiów & 34,0 & 38,5 & 24,8 & 26,3 & 32,9 \\
\hline Nie zastanawiałem się & 21,5 & 13,8 & 10,0 & 16,7 & 20,6 \\
\hline
\end{tabular}

Źródło: badania własne w ramach projektu KBN - NN 116438837

W przeprowadzonych badaniach zajmowanie stanowisk kierowniczych nie należy do najpilniejszych i najsilniejszych aspiracji wśród badanych studentów. Stosunkowo najwyższe jest w Czecha i Polsce ale po upływie dłuższego okresu po ukończeniu studiów.

\begin{tabular}{|c|c|c|c|c|c|}
\hline 8. Wlasna firma & Czechy & Litwa & Ukraina & Rosja & Polska \\
\hline Cel osiągnięty & 1,9 & 1,4 & 1,0 & 1,3 & 1,7 \\
\hline Cel w trakcie osiągania & 2,2 & 3,3 & 7,8 & 4,3 & 2,3 \\
\hline Do 3 lat po ukończeniu studiów & 2,7 & 3,1 & 10,2 & 10,0 & 3,9 \\
\hline Do 5 lat po ukończeniu stduiów & 4,9 & 5,5 & 18,0 & 15,4 & 5,6 \\
\hline $\begin{array}{c}\text { Później niż 5 lat po ukończeniu } \\
\text { studiów }\end{array}$ & 11,1 & 16,7 & 15,0 & 14,3 & 13,9 \\
\hline $\begin{array}{c}\text { Nie zastanawiałem się } \\
\text { Nie zamierzam realizować tego } \\
\text { celu }\end{array}$ & 39,3 & 44,4 & 28,0 & 30,8 & 38,6 \\
\hline
\end{tabular}

Źródło: badania własne w ramach projektu KBN - NN 116438837 
Prowadzenie własnej działalności gospodarczej również znajduje się raczej poza orbitą najważniejszch zainteresowań badanych osób. Mimo sprzyjających warunków najniższy odsetek zainteresowanych osób zadeklarowali studenci z Czech i Polski.

\begin{tabular}{|c|c|c|c|c|c|}
\hline $\begin{array}{c}\text { 9. Wysoka pozycja we władzy } \\
\text { państwowej }\end{array}$ & Czechy & Litwa & Ukraina & Rosja & Polska \\
\hline Cel osiągnięty & 0,3 & 0 & 0,7 & 0,6 & 0,4 \\
\hline Cel w trakcie osiągania & 0,7 & 1,0 & 5,8 & 2,8 & 0,5 \\
\hline Do 3 lat po ukończeniu studiów & 2,2 & 2,3 & 6,9 & 5,3 & 1,7 \\
\hline Do 5 lat po ukończeniu studiów & 5,0 & 4,7 & 10,8 & 6,9 & 2,1 \\
\hline Później niż 5 lat po ukończeniu studiów & 14,5 & 13,0 & 9,7 & 7,0 & 6,5 \\
\hline Nie zastanawiałem się & 35,2 & 42,8 & 24,6 & 23,6 & 27,2 \\
\hline Nie zamierzam realizować tego celu & 36,9 & 35,8 & 32,9 & 50,6 & 60,7 \\
\hline
\end{tabular}

Źródło: badania własne w ramach projektu KBN - NN 116438837

Zajmowanie wysokiej pozycji we władzach państwowych również nie należy do podstawowych wartości studentów w badanych krajach. Po zakończeniu studiów jedynie w Czechach i na Litwie zainteresowanianie piastowaniem takich stanowisk wzrasta.

\begin{tabular}{|c|c|c|c|c|c|}
\hline $\begin{array}{c}\text { 10. Wysoka pozycja we władzy } \\
\text { lokalnej }\end{array}$ & Czechy & Litwa & Ukraina & Rosja & Polska \\
\hline Cel osiągnięty & 0,8 & 0,1 & 0,1 & 0,6 & 0,3 \\
\hline Cel w trakcie osiągania & 0,6 & 1,0 & 5,5 & 2,5 & 1,4 \\
\hline Do 3 lat po ukończeniu studiów & 1,5 & 2,5 & 6,5 & 3,9 & 1,4 \\
\hline Do 5 lat po ukończeniu studiów & 2,7 & 4,7 & 8,8 & 4,7 & 3,0 \\
\hline Później niż 5 lat po ukończeniu & 6,5 & 9,0 & 8,6 & 5,9 & 5,4 \\
\hline studiów & 37,8 & 44,4 & 25,4 & 24,2 & 29,3 \\
\hline Nie zastanawiałem się & 44,7 & 37,5 & 36,0 & 55,0 & 58,5 \\
\hline
\end{tabular}

Źródło: badania własne w ramach projektu KBN - NN 116438837

Jeszcze mniejsze jest zainteresowanie aktywnym udziałem w strukturach władzy lokalnej, które nie przekracza procent. Można to thumaczyć systematycznym niszczeniem znaczenia i etosu władzy lokalnej oraz samorządności, w ramach poprzedniego systemu i podkreślanie znaczenia władzy państwowej. 


\begin{tabular}{|c|c|c|c|c|c|}
\hline 11. Udział w elicie władzy & Czechy & Litwa & Ukraina & Rosja & Polska \\
\hline Cel osiągnięty & 1,6 & 0,3 & 0,6 & 0,4 & 0,3 \\
\hline Cel w trakcie osiągania & 1,4 & 1,3 & 4,6 & 2,9 & 1,1 \\
\hline Do 3 lat po ukończeniu studiów & 2,6 & 2,0 & 6,2 & 3,7 & 1,4 \\
\hline Do 5 lat po ukończeniu studiów & 5,2 & 3,3 & 9,3 & 5,1 & 1,5 \\
\hline Później niż 5 lat po ukończeniu \\
studiów & 14,0 & 9,3 & 9,6 & 6,7 & 5,4 \\
\hline Nie zastanawiałem się & 31,4 & 41,0 & 26,5 & 24,7 & 25,5 \\
\hline Nie zamierzam realizować tego celu & 38,3 & 42,4 & 34,2 & 53,5 & 63,9 \\
\hline
\end{tabular}

Źródło: badania własne w ramach projektu KBN - NN 116438837

Poza jednostkowym przypadkiem Czech w pozostałych badanych krajach nie stwierdzono większego zainteresowania aktywnym udziałem w elicie władzy. Poziom zainteresowania nie przekroczył, poza wspomnianym wyjątkiem, 10 procent. Wynika to, podobnie jak w poprzednim przypadku z niskiego prestiżu społecznego organów władzy. Najniższy poziom zainteresowani w Polsce wynika również z jakości życia politycznego i prywatnego elit władzy po 1989r.

\begin{tabular}{|c|c|c|c|c|c|}
\hline 12. Bogactwo & Czechy & Litwa & Ukraina & Rosja & Polska \\
\hline Cel osiągnięty & 0,9 & 0,7 & 1,0 & 0,9 & 0,6 \\
\hline Cel w trakcie realizacji & 3,9 & 5,7 & 15,3 & 11,1 & 3,5 \\
\hline Do 3 lat po ukończeniu studiów & 5,8 & 3,2 & 11,2 & 11,8 & 7,8 \\
\hline Do 5 lat po ukonczeniu studiów & 13,8 & 8,6 & 15,6 & 14,0 & 14,9 \\
\hline Później niż 5 lat po ukończeniu & 33,5 & 36,2 & 19,3 & 24,9 & 35,5 \\
\hline studiów & 21,9 & 30,0 & 19,2 & 19,2 & 24,2 \\
\hline Nie zastanawiałem się & 14,5 & 15,0 & 8,6 & 14,5 & 12,6 \\
\hline
\end{tabular}

Źródło: badania własne w ramach projektu KBN - NN 116438837

Bogacenie się jako wartość docelowa wśród studentów stosunkowo najwyższy poziom osiąga w Polsce i na Litwie a najniższy w Rosji i na Ukrainie. Sytuacja taka może być związana z możliwościami prawnymi bogacenia się i stosunkiem do bogacenia się w ramach tzw. szarej strefy. 


\begin{tabular}{|c|c|c|c|c|c|}
\hline 13. Nowy samochód & Czechy & Litwa & Ukraina & Rosja & Polska \\
\hline Cel osiągniety & 5,3 & 2,0 & 1,8 & 3,3 & 3,0 \\
\hline Cel w trakcie realizacji & 3,9 & 4,7 & 12,2 & 13,1 & 3,1 \\
\hline Do 3 lat po ukończeniu studiów & 16,4 & 5,5 & 16,8 & 20,7 & 15,9 \\
\hline Do 5 lat po ukończeniu studiów & 17,0 & 6,9 & 13,7 & 12,8 & 17,9 \\
\hline Później niż 5 lat po ukończeniu \\
studiów & 17,0 & 20,4 & 18,0 & 18,5 & 25,7 \\
\hline Nie zastanawiałem się & 16,6 & 27,8 & 15,0 & 14,9 & 18,8 \\
\hline Nie zamierzam realizować tego celu & 18,3 & 32,4 & 12,8 & 13,9 & 14,8 \\
\hline
\end{tabular}

Źródło: badania własne w ramach projektu KBN - NN 116438837

Posiadanie własnego nowego samochodu ma stosunkowo największe znaczenia dla studentów z Rosji i Ukrainy a zdecydowanie najniższe z Czech. Wynika to ze stopnia nasycenia infrastrukturą komunikacyjną danego kraju oraz z jego rozległości terytorialnej.

\begin{tabular}{|c|c|c|c|c|c|}
\hline 14. Własne mieszkanie & Czechy & Litwa & Ukraina & Rosja & Polska \\
\hline Cel osiągnięty & 5,0 & 4,6 & 8,0 & 7,5 & 6,9 \\
\hline Cel w trakcie realizacji & 5,9 & 5,7 & 15,0 & 12,5 & 5,2 \\
\hline Do 3 lat po ukończeniu studiów & 21,9 & 8,9 & 20,4 & 20,4 & 25,9 \\
\hline Do 5 lat po ukończeniu studiów & 23,6 & 17,0 & 17,3 & 18,2 & 27,4 \\
\hline Później niż 5 lat po ukończeniu \\
studiów & 22,4 & 43,3 & 22,3 & 24,7 & 22,4 \\
\hline Nie zastanawiałem się & 8,5 & 13,4 & 5,9 & 10,4 & 6,4 \\
\hline Nie zamierzam realizować tego celu & 7,3 & 6,5 & 2,8 & 3,3 & 5,0 \\
\hline
\end{tabular}

Źródło: badania własne w ramach projektu KBN - NN 116438837

Zainteresowanie posiadaniem własnego mieszkania jest najwyższe wśród mieszkańców Ukrainy i Polski. W większości badanych krajów realizacja tej wartości oczekiwana jest w granicach 5 lat po ukończeniu studiów.

\begin{tabular}{|c|c|c|c|c|c|}
\hline 15. Własny dom & Czechy & Litwa & Ukraina & Rosja & Polska \\
\hline Cel osiągnięty & 3,2 & 0,9 & 4,7 & 4,3 & 1,9 \\
\hline Cel w trakcie realizacji & 3,6 & 4,1 & 13,7 & 8,4 & 2,3 \\
\hline Do 3 lat po ukończeniu studiów & 5,8 & 4,0 & 16,2 & 12,3 & 7,0 \\
\hline
\end{tabular}




\begin{tabular}{|c|c|c|c|c|c|}
\hline Do 5 lat po ukończeniu studiów & 11,3 & 7,0 & 18,3 & 17,9 & 13,3 \\
\hline $\begin{array}{c}\text { Później niż 5 lat po ukończeniu } \\
\text { studiów }\end{array}$ & 35,3 & 46,0 & 19,3 & 20,4 & 43,0 \\
\hline Nie zastanawiałem się & 21,8 & 28,3 & 13,6 & 25,1 & 20,2 \\
\hline Nie zamierzam realizować tego celu & 14,2 & 9,3 & 4,6 & 8,2 & 11,6 \\
\hline
\end{tabular}

Źródło: badania własne w ramach projektu KBN - NN 116438837

Najwyższy poziom zainteresowania posiadaniem własnego domu mieszkalnego zdecydowanie istnieje wśród studentów z Ukrainy wynosząc ok 80 procent badanych osób. W pozostałych krajach oscyluje na podobnym poziomie ok. 65 procent.

\begin{tabular}{|c|c|c|c|c|c|}
\hline 16. Malżeństwo & Czechy & Litwa & Ukraina & Rosja & Polska \\
\hline Cel osiągnięty & 1,3 & 2,5 & 4,6 & 5,0 & 3,5 \\
\hline Cel w trakcie realizacji & 4,8 & 8,1 & 18,4 & 21,3 & 5,9 \\
\hline Do 3 lat po ukończeniu studiów & 15,2 & 18,0 & 19,0 & 22,2 & 23,6 \\
\hline Do 5 lat po ukończeniu studiów & 23,4 & 21,1 & 14,6 & 11,3 & 24,4 \\
\hline Później niż 5 lat po ukończeniu studiów & 25,1 & 22,7 & 17,1 & 15,4 & 21,9 \\
\hline Nie zastanawiałem się & 18,5 & 22,4 & 12,5 & 16,8 & 14,9 \\
\hline Nie zamierzam realizować tego celu & 6,7 & 4,9 & 5,0 & 5,6 & 5,2 \\
\hline
\end{tabular}

Źródło: badania własne w ramach projektu KBN - NN 116438837

Wśród deklarowanych wartości zawarcie związku małżeńskiego jest jednym $\mathrm{z}$ najszybciej realizowanych sród studentów z Rosji i Ukrainy, a zdecydowanie wolniej, po ukończeniu studiów przez pozostałych studentów. Wczesne zawieranie małżeństw może znaleźć swój efekt w wysokim odsetku rozwodów np. w Rosji /patrz Tab. 3/.

\begin{tabular}{|c|c|c|c|c|c|}
\hline 17. Dzieci & Czechy & Litwa & Ukraina & Rosja & Polska \\
\hline Cel osiągnięty & 0,8 & 0,8 & 2,2 & 1,4 & 2,4 \\
\hline Cel w trakcie realizacji & 1,6 & 2,4 & 7,4 & 6,4 & 1,9 \\
\hline Do 3 lat po ukończeniu studiów & 14,0 & 12,8 & 15,6 & 19,5 & 13,9 \\
\hline Do 5 lat po ukończeniu studiów & 24,4 & 22,4 & 19,6 & 20,1 & 18,5 \\
\hline Później niż 5 lat po ukończeniu & 27,0 & 24,8 & 17,4 & 18,4 & 30,1 \\
\hline studiów & 22,0 & 31,0 & 24,2 & 26,9 & 26,0 \\
\hline Nie zastanawiałem się & 5,1 & 5,8 & 4,0 & 4,5 & 6,6 \\
\hline
\end{tabular}

Źródło: badania własne w ramach projektu KBN - NN 116438837 
Posiadanie dzieci jest znaczącą wartością we wszystkich badanych krajach i oscyluje na podobnym poziomie ponad 60 procent. W zdecydowanej większości cel ten respondenci zdeklarowali się realizować po ukończeniu studiów.

\section{WNIOSKI}

Wartości deklarowane przez studentów są zdecydowanie częściej obecne w życiu codziennym niż $\mathrm{w}$ funkcjonowaniu struktur społecznych o charakterze instytucjonalnoorganizacyjnym. Wartości te niezależnie od ich faktycznej realizacji stają się faktami kulturowymi. Gdy zostają one zsyntetyzowane razem z systemem potrzeb i działania, są w stanie zobrazować podstawowe orientacji życia ludzi w danym kraju i kulturze.

\section{References}

[1] Sztompka P., Kulturowe imponderabilia szybkich zmian społecznych. Zaufanie, lojalność, solidarność., Studia Socjologiczne 4(147) (1997).

[2] Cybulska A., Zaufanie społeczne, raport CBOS BS/33/2012, Warszawa 2012, s. 3.

[3] Borowski A., International Letters of Social and Humanistic Sciences 3 (2013) 69-74.

[4] Borowski A., International Letters of Social and Humanistic Sciences 14 (2014) 7-17.

[5] Borowski A., International Letters of Social and Humanistic Sciences 14 (2014) 33-41.

[5] Borowski A., International Letters of Social and Humanistic Sciences 7 (2013) 113-118.

[6] Borowski A., International Letters of Social and Humanistic Sciences 2 (2013) 56-60.

[7] Susanne Y. P. Choi, Roman David, American Journal of Sociology 117(4) (2012) 1172-1201.

[8] Jeffrey C. Goldfarb, American Journal of Sociology 83(4) (1978) 920-939.

[9] Amy C. Butler, Social Service Review 69(1) 1995) 1-30.

[10] Francis J., B. Giles-Corti, L. Wood, M. Knuiman. Journal of Environmental Psychology 32(4) (2012) 401-409.

[11] Cattell V., N. Dines, W. Gesler, S. Curtis, Health \& Place 14(3) 2008) 544-561.

[12] Goodman B., Nurse Education Today 33(2) (2013) 81-82.

[13] Oprea-Valentin Buşu, International Letters of Social and Humanistic Sciences 12 (2014) 41-48.

[14] Peter Emerson, International Letters of Social and Humanistic Sciences 12 (2014) 90-109. 
[15] Ștefan Vlăduțescu, International Letters of Social and Humanistic Sciences 10(2) (2014) 100-106.

[16] Alexandra Iorgulescu, International Letters of Social and Humanistic Sciences 7 (2014) $14-21$.

[17] Ștefan Vlăduțescu, International Letters of Social and Humanistic Sciences 7 (2014) 8-13. 